\title{
TUJUH BUDAYA MASYARAKAT PEGUNUNGAN: REPOSISI PESANTREN SEBAGAI PEMBIMBING MASYARAKAT
}

\author{
Ahmad Halid \\ Universitas Islam Jember \\ khalidghunung@gmail.com
}

Received: 11-12-2020

Revised: 10-01-2021

Accepted: 27-01-2021

\section{SEVEN CULTURES OF MOUNTAIN COMMUNITIES: Repositioning of Islamic Boarding Schools as Community Guides}

\begin{abstract}
Abstrak:
Budaya merupakan beliefs, norms, values, asumtions yang dipegang teguh oleh masyarakat. Metode penelitian yang ditentukan yaitu dengan pendekatan kualitatif dan pengumpulan data observasi, interview dan dokumentasi. Analisis data menggunakan model Miles dan Huberman. Tujuannya adalah untuk mengembangkan dan menyebarluaskan tujuh budaya masyarakat pegunungan. Masyarakat yang maju adalah masyarakat yang tinggi kesadaran berbudaya dan mempertahankan budayanya. Budaya masyarakat pegunungan yang dimaksud adalah budaya Amaen paraben (penentuan jodoh), budaya (aghelluk) pencak (aduh kekuatan otot dan ilmu kanoragan), budaya Sihir/Guna-guna, budaya Toktok (persatuan aduan sapi), budaya ngalak cbukok kalaot (gotong royong menangkap ikan dalam rangka tasyakuran pernikahan atau salamatan anak khatam al-qur'an, selamatan tiga, tujuh, empat puluh, seratus hari meninggalnya seseorang atau hajatan lainnya), budaya salamatan janur katopak (salamatan desa) dan budaya kalongan katopak dan jhubethe sapi. Tujuh budaya ini telah diseleksi dan diwarnai oleh pesantren sehingga menjadi budaya yang bermanfaat bagi kehidupan masyarakat
\end{abstract}

Kata Kunci: Tujub budaya masyarakat, kepercayaan masyarakat, reposisi pesantren

\begin{abstract}
:
Culture is beliefs, norms, values, assumptions held by the community. The research method was determined by using a qualitative approach and collecting observation, interview and documentation data. Data analysis using the Miles and Huberman model. A developed society is a society that is bighly cultured and maintains its culture. Mountain culture is the culture of Amaen paraben (matchmaking), culture (aghelluk) pencak (ocular strength and kanoragan science), Magic / Gunause culture, Toktok culture (united cattle complaints), ngalak cbukok kalaot culture (mutual cooperation to catch fish) in the context of marriage or kalamam children greeting khatam al-qur'an, salvation three, seven, forty, one bundred days of death of a person or other celebration), salamatan janur katopak (village salamatan) culture and kalongan katopake and jbubethe cattle culture. These seven cultures have been selected and colored by pesantren so that it becomes a culture that is beneficial to people's lives.
\end{abstract}

Keywords: seven cultural communities, repositioning pesantren. 


\section{PENDAHULUAN}

Budaya adalah kumpulan nilai dasar, persepsi, keyakinan, keinginan dan norma perilaku yang dipelajari oleh anggota masyarakat dari keluarga dan institusi penting lainnya. ${ }^{1}$ Robbins dan Judge menjelaskan budaya adalah suatu sistem nilai yang dipegang dan dilakukan oleh anggota organisasi(masyarakat)yang sedemi-kian menjadi pembeda organisasi(masyarakat) tersebut dengan organisasi (masyarakat) ${ }^{2}$. Stok, Markic, Bertoncelj and Mesko menjelaskan Cultures basically spring from three sources, (1) the beliefs, values, and assumptions on founders of organization;(2) the learning experiances of group members as their organization evolves; and (3) new beliefs, values, and assumptions brought in by new members and leaders. Ahmed dan Shafiq Culture can be defined as a combination of values, sets, beliefs, communications and simplification of behaviour which gives direction to peoples. ${ }^{3}$

Budaya pada dasarnya berasal dari tiga sumber, (1) kepercayaan, nilai, dan asumsi pada pendiri organisasi; (2) pengalaman belajar anggota kelompok saat organisasi mereka berkembang; dan (3) kepercayaan, nilai, dan asumsi baru yang dibawa oleh anggota dan pemimpin baru). Ahmed dan Shafiq mendefinisikan sebagai kombinasi antara nilai, set, kepercayaan, komunikasi dan penyederhanaan perilaku yang memberi arahan kepada masyarakat.

Kotter and Heskett "culture means fairly established set of beliefs, behaviors and values of society contain generally".(Budaya berarti seperangkat keyakinan, perilaku, dan nilai masyarakat yang mapan cukup umum. Sedangkan Joson Martin berpendapat bahw Culture provides meaning to the work of the organization by allowing members to be part of something larger than themselves, ensures members abide by organizational norms, and frames the outside world so its members can more easily interpret reality. ${ }^{4}$ (budaya memberi makna pada pekerjaan organisasi dengan membiarkan anggota menjadi bagian dari sesuatu yang lebih besar dari pada dirinya sendiri, memastikan anggota mematuhi norma organisasi dan membingkai dunia luar sehingga anggotanya dapat lebih mudah menafsirkan kenyataan). Menurut Amin Nikpour "culture is a pattern of shared basic assumptions.

Mengkaji budaya maka tidak akan lepas dari teori corporate culture, karena pertama kali berkembang ilmu budaya adalah di bidang corporate (perusahaan atau pabrik) karena itu maka istilah budaya yang dikembangkan dalam penelitian ini banyak merujuk pada disiplin corporate culture "Corporate culture refers to the shared values, attitudes, standards, and beliefs that characterize members of an organization and define its nature. Corporate culture is rooted in an organization's goals, strategies, structure, and approaches to labor, customers, investors, and the greater community" "Budaya perusahaan mengacu pada nilai-nilai bersama, sikap, standar, dan kepercayaan yang menjadi ciri anggota organisasi dan menentukan sifatnya. Budaya perusahaan berakar pada tujuan,

\footnotetext{
${ }^{1}$ Philip Kotler, and Gary Armstrong, 2006. Principles of Marketing. Penerjemah; Pop Sabran, Prinsip-Perinsip Pemasaran, Edisi 12. Jakarta; Erlangga, 159

2 Robbins, Stephen P and Judge 1987. Organizational Behavior. New York: Printice Hall, 322

3 Stok, Markic, Bertoncelj and Mesko, Elements of organizational culture leading to business excellence(Preliminary communication) UDC 658:304.2:316.776. Zb. rad. Ekon. fak. Rij. • $2010 \bullet$ vol. 28 • sv. 2 • 303318), 22

${ }^{4}$ Kotter, J. P. \& Heskett, J. L. (1992). Corporate culture and performance. New York: Free Press, 460

${ }_{5}$ Amin Nikpour, The impact of organizational culture on organizational performance: The mediating role of employee's organizational commitment. International Journal of Organizational Leadership 6 (2017) 66

${ }^{6}$ https:/ / www.inc.com > encyclopedia
} 
strategi, struktur, dan pendekatan organisasi terhadap tenaga kerja, pelanggan, investor, dan komunitas yang lebih luas)

Setiap kelompok masyarakat memiliki kebiasaan, cara dan normasendiri-sendiri dalam mengekspresikan uuntuk mencapai tujuan hidup kelompoknya dan masyarakat tersebut memiliki cara hidupyang berbeda dalam mengatasi berbagai permasalahan atau problematika yang dihadapi dalam kelompok. Kehidupan berkelompok tersebut tentu didasarkan pada belief (keyakinan) dan values (nilai-nilai), norm (aturan), assumption (asumsi) sebagaimana yang telah dijelasan oleh Kotter and Heskett, Ahmed dan Shafiq daan lainnya di atas. keyakinan dan nilainilai tersebut dipegang erat oleh mereka yang didasarkan pada philosophy hidup untuk mencapai hidup manusia bersama dengan lingkungan sekitarnya. hubungan lingkungan hidup yang dimaksud adalahhubungan dengan alam, tumbuh-tumbuhan, binatang, dan manusiaitu sendiri berjalan harmonis.

Tujuh budaya masyarakat pegunungan yang dimaksud adalah pertama, budaya Amaen Paraben (penentuan jodoh). kedua, budaya Aghelluk atau pencak (aduh kekuatan otot dan ilmu kanoragan, ketiga, budaya Sihir atau Guna-guna. Keempat, budaya Toktok (persatuan aduan sapi. Kelima, budaya ngalak chukok kalaot (gotong royong menangkap ikan dalam rangka tasyakuran pernikahan atau salamatan anak khatam al-qur'an). Keenam, budaya salamatan janur katopak (salamatan desa) dan ketujuh, budaya kalongan katopak dan jhubethe sapi.

Penulis sangat tertarik untuk mengkaji secara mendalam tentang tujuh budaya yang dilaksanakan di masyarakat pegunungan tersebut, sebab, sejak kecil peneliti bagian dari masyarakat pegunungan itu yang menyaksikan manfaatnya bagi perkembangan masyarakat tersebut, termasuk menjadi saksi budaya itu dilangsungkan di tengah-tengah masyarakat.

\section{METODE PENELITIAN}

Metode penelitian ini mengguaka pendekatan kualitatif deskriptif dan proses pengumpulan data menggunakan metode observasi, interview dan dokumentasi. Analisis data hasil penelitian ini menggunakan model Miles dan Huberman. Penelitian ini dilaksanakan di Dusun pategalan dan sekitarnya yang beralamat Dusun Pategalan Desa kelompanggubug Tambak Bawean Gresik.

Data penelitian ini akan memperkuat dengan data etik dan data emik, kedua jenis data penelitian ini menjadi sumber otoritatif di dalam memberikan analisis, komentar atau menyimpulkan temuan penelitian. Sistem keabsahan data yang digunakan peneliti adalah konfermabilitas data sangat ditekankan agar hasil penelitian ini tidak bertentangan dengan realitas di lapangan. Dengan motode penelitian ini maka hasil penelitian ini dapat dipertanggung jawabkan kebenarannya.

\section{HASIL DAN PEMBAHASAN}

Tujuh budaya masyarakat pegunungan yang dimaksud antara lain budaya Amaen paraben (penentuan jodoh), budaya (aghelluk) pencak (aduh kekuatan otot dan ilmu kanoragan), budaya Sihir/Guna-guna, budaya Toktok (persatuan aduan sapi), budaya ngalak chukok kalaot (gotong royong menangkap ikan dalam rangka tasyakuran pernikahan atau salamatan anak khatam alqur'an atau hajatan lainnya), budaya salamatan janur katopak (salamatan desa) dan budaya kalongan katopak dan jhubethe sapi. 


\section{Budaya Amaen ka paraben (budaya mencari jodoh)}

Budaya adalah penataan atribut yang berbeda yang mengekspresikan sebuah organisasi dan membedakan perusahaan dari yang lain. ${ }^{7}$ Menurut Hofstede (1980), budaya adalah pemikiran kolektif dari pikiran yang menciptakan perbedaan antara anggota satu kelompok dari kelompok lain. ${ }^{8}$ Sesuai Schein (1990), mendefinisikan budaya adalah serangkaian nilai dan perilaku yang berbeda yang dapat dianggap sebagai panduan menuju kesuksesan. ${ }^{9}$ Menurut Kotter dan Heskett (1992), budaya berarti seperangkat keyakinan, perilaku, dan nilai masyarakat yang mapan cukup umum..$^{10}$ Dengan kata sederhana kita dapat memahami bahwa budaya memperoleh pengetahuan, penjelasan, nilai, kepercayaan, komunikasi dan perilaku sekelompok besar orang, pada saat bersamaan dan tempat yang sama. ${ }^{11}$

Dari teori budaya tersebut, maka Amaen merupakan bagian dari budaya masyarakat. Kata Amaen atau amaenana dalah istilah yang digunakan oleh masyarakat pegunungan berbeda makna dengan kata bermain (bahasa Indonesia). kata amaen adalah budaya khas masyarakat pegunungan untuk mencari jodoh atau perkenalan antara parjheka dengan paraben.

Peneliti sebelum dipondokkan oleh kedua orang tuatahun 1994 sering menyaksikan para parjbeka dan paraben (pemuda-pemudi desa) si parjheka amaen (mencari paraben untuk berkenalan)ke lain kampung di malam hari untuk mencari pasangan hidupnyadengan caramenempati salah satu tempat khusus yang ditentukan oleh para parabenuntuk melayani perkenalan seorang parjeka yang diasumsikan untuk menentukan jodohnya sendiri tampa ada proses penjodohan orang tua. Ditempat ini pasangan parjheka dan parabenmemilih pasangan sendiri yang sesuai dengan keinginannya. Prosesamaen ini dilakukan pada malam hari sekitar jam 20;00 hingga jam 03:30 atau sebelum shalat subuh. tentu di tempat ini sekelompok paraben mengatur tempatnya dengan rapidan aman yang nantinya dijadikan tempatta'arruf atau saling perkenalan dengan tamu (parjheka)yang berdatangan dari lain kampung atau lingkungan sendiri.

Proses Amaen Paraban ini tentu menghilangkan budaya perjodohan oleh orang tua pihak laki-laki atau orang tua pihak wanita. Bagi waita dan peria desa peguungan ini proses penjodohan merupakan budaya yang tidak diinginkan dan sangat menyakitkan perasaan mereka. Karena itu, orang tua pegunungan tersebut nasib jodoh anak-anaknya ditentukan anak-anak, apapun pilihan anaknya orang tua merestuinya.

Tempat-tempat yang sering penulis jumpai dalam proses Amaen Paraban ini antara lain Dusun Pategalan, dusun batu celeng, dusun celok-celok, dusun kalacok, dusun pasar, dusun laok sabheh, dusun candi, dusun kepongan, dusun ghenteria, dusun phelikphek, dusun panyalpangan, dusun songai teros, dusun tanah merah,dusun langkap, dan dusun-dusun kecil lain yang berdampingan dengan dusun-dusun tersebut, sesungguhnya masih banyak tempat lain yang belum disebutkan.

${ }^{7}$ Forehand, G. A. and Von Gilmer, (1964). Environmental Variations in Studies of Organizational Behavior. Psychological Bulletin, 62, 361-382.

${ }^{8}$ Hofstede, G. Bond, M. H. (1998). The Confucius Connection: from Cultural Roots to Economic Growth. Organ Dyn, pp. 5-21.

${ }_{9}$ Schein, E. H. (1990). Organizational culture. American Psychologist, 43 (2), 109-119.

${ }^{10}$ Kotter, J. P. \& Heskett, J. L. (1992). Corporate..34

${ }^{11}$ Fakhar Shahzad, Rana Adeel Luqman, Ayesha Rashid Khan, Lalarukh Shabbir, Impact of Organizational Culture on Organizational Performance: An Overview INTERDISCIPLINARY JOURNAL OF CONTEMPORARY RESEARCH IN BUSINESS, JANUARY 2012 VOL 3, NO 9, 3 
Respon masyarakat pada budaya amaen ka parabentersebut menerima, ada kalanya biasabiasa saja, ada pula masyarakat menganggapnya sebagai strategi untuk mengawinkan pemuda dan pemudi desa utamanya mereka yang telah sampai usia pernikahan atau mereka yang telah melebihi usianya adalah menjadi skala prioritasuntuk segera menemukan pendamping hidupnya dan sagat dibantu dengan budaya iini.

Selain itu, ketika sudah ketahuan selama 3 malam berkenalan sepasang paraben dan parjheka berduaan, maka, perwakilan masyarakat yang ditokohkan menangkapnya dan ditunangkan lalu berlanjut pada hubungan yang sangat serius yaitu pernikahan. Masyarakat tidak mentolerir kepada parjheka dan paraben yang tertangkap amaen walaupun masih usia mudah harus mau ditunangkan dan menikah.

Budaya tersebut kelihatan jelek menurut penilaian daerah lain, tetapi menurut masyarakat pegunungan tersebut justru menandakan sebagai pelentara penentuan jodoh. Anak-anak yang perempuan ketika dimaeni (didatangi seorang parjheka) menandakan anak itu laku dan disukai orang karena itu anak tersebut dikatakan cantik. Sehingga hal itu dipahami sudah ada yang suka dan perasaan orang tuanya pun terasa lega karena sudah ada parjhekayang menyukainyakedepannya anaknya pasti laku tidak menjadi beban yang berat bagi orang tuanya karena salah satu kewajiban orang tua adalah menikahkan putra-putrinya.

Dari sebagian teman perempuan itu atau orang lan yang mengetahuinya maka ada yang memberi tahu kepada orang tuanya bahwa anaknya e maene (e ka terro e/disukai seseorang), informasi itu sampai pada orang tua si paraben, lalu ia (orang tua paraben)secara diam-diam mencari tahu siapa laki-laki itu, kemudian perwakilan daritokoh masyarakat bersama pemuda setempat menggerebek lalu di tangkapnya.kemudian orang tua paraben itu, akan mendatangi orang tua parjheka itu dalam rangka merencanakan lamaran yang bakal dinikahkan (jika ada kecocokan). Akan tetapi proses budaya amaen paraben ini memiliki dampak yang negative dan dilarang oleh syariat, diantaranya yaitu: 1) sering kali terjadi hamil duluan sebelum ditangkap karena tidak ada yang tahu sehingga proses penangkapan atau penggerebekan terlambat. 2) adakalanya menjadi pemuasan hawa nafsu (bidonisme), dan bersenang-senang belaka. 3) ada niat permainan parjheka untuk bersenang-senang bersama paraben, setelah itu ditinggal, tampa meninggalkan jejak (ditinggal pergi merantau atau pergi kemana yang tidak diketabui orang). ${ }^{12}$

Tetapi ketiga dampak negative tersebut selamadalam pengamatan peneliti dapat diatasi dan bisa dibilang sangat kecil kemungkinanya. karena pihak orang tua dan para tokoh warga masyarakat mewaspadai dan responsifserta mengintai gerakan parjheka dan paraben di liingkungan, karena budaya amaen ini bagian dari budaya penentuan jodoh di daerah pegunungan tersebut tidak ada system penjodohan, urusan jodoh diserahkan kepada anak masing-masing karena ada anggapan yang kuat dikalangan masyarakat 'yang mau nikah itu anaknya bukan orang tuanya' karena itu kesenangan dan kecintaan itu yang menentukan adalah anak itu sendiri bukan orang tua, hanya saja orang tua memberikan motivasi dan pertimbangan yang matang, sedangkan keputusan berada pada anak itu sendiri.

Proses amaenan, sekarang ini pada umumnya sudah luntur, bahkan sudah dibilangsangat kecil karena tingkat pengetahuan masyarakat dan orang tua sudah semakin meningkat dan masyarakat umum memahaminya budaya amaen paraben itu adalah bagian dari budaya yang

\footnotetext{
12 Jamal. Interview. 12 Maret 2018
} 
terlarang menurut syariat Islam. kesadaran masyarakat tersebut, tentu peran besar pesantren memberantas budaya tersebutdengan bekerja samadari berbagai pihak seperti sekolah formal yang ada dilingkungan tersebut, tokoh masyarakat dan kyai, alumni dan santri yang menggugah orang tua agar menjaga paraben dan parjheka jangan sampai bertemu, pacaran, berduaan, karena akan mudah dipengaruhi syaithan dan pada akhirnya menimbulkan fitnah dan dapat menimbulkan bencana besar.

Banyak cara yang dilakukan pesantren dalam pengikisan budaya amaen paraben tersebut diantaranya adalah pertama pihak pesantren bekerjasama dengan masjid, mushalla melalui pengajian umum dalam memperingati hari besar islam seperti isra' mi'raj, peringatan mauled nabi Muhammad, puasa Ramadlan. kyai-kyai pengasuh pesantren yang dipandang kharismatik dan punya metode ceramah yang diterima masyarakat diundang dan berceramahlah disitu. dari isi ceramah itulah masyarakat akan tergugah untuk melarang budaya parjheka amaen paraben.

Kedua, dengan cara pesantren mengkader generasi mudah yang kebetulan bersal dari daerah yang melaksanakan budaya amaen perempuan, ketika mereka keluar dari pesantren dan pulang kemasyarakatnya mereka meneruskan perjuangan kyai pesantren untuk menolak budaya tersebut dan memberikan penjelasan dampak negatifnya kepada orang tua dan paraben. usaha tersebut berhasil sehingga budaya amaen saat ini secara sendirinya hilang dan kesadaran parjheka dan peraben sangat tinggi untuk menlanjutkan sekolah ke jenjang yang lebih tinggi "tidak tergesa-gesa untuk menikah". karena mudah atau tua, suka atau tidak, ketika ketemu amaen paraben dan ditangkap oleh masyarakat, maka harus memanggil orang tuanya untuk meminta dan melamarnya. disinilah paraben dan parjheka mengahkiri masa paraben dan parjheka menuju pasangan suami istri yang sah dan diridlai oleh Allah.

\section{Budaya aghelluk pencak (aduh kekuatan otot dan ilmu kanoragan yang disisipkan)}

Istilah yang digunakan oleh masyarakat pegunungan adalah pencak (bukan pencaksilat tapi pencak) asal bawean. yang menggunakan istilah pencaksilat hanya penggemar saja dan penulis. ${ }^{13}$ bukan orang pegunungan atau bukan pendekarnya.pendekar maupun peserta pencak menggunakan istilah pencak atau mencak. Masyarakat pegunungan yang dimaksud adalah penduduk asli bawean yang menempati dataran tinggi bersebelahan dengan gunung-gunung di baweanseperti dusun pategalan, kalocok, batu celeng, dusun celok-celok, dusun pasar, dusun tanah merah, dusun phelikphek, dusun kepongan, dusun ghenteria, dusun pasar talaghe, dusun canthi, dusun laok sabheh, dusun sangar, dusun panyalpangan dan lain-lain.

sesungguhnya masyarakat pegunungan tidak menyebutkan kata pencaksilat, tetapi hanya menyebutkan pencak tampa silat. pencak menurut budaya masyarakat pegunungan adalah identik dengan akbelluk.

Penulis sejak mudah belajar pencakpada pendekar pencak yang ada di desa pategalan. hampir tiap hari bersma teman-teman bermain bertarung aduh kekuatan fisik (aghelluk) saling banting (angkessaken) bahkan pertarungan ini disaksikan oleh pendekarnya (pelatihnya) dan dilihat oleh orang banyak di desa itu. sang pendekar melihat anak didiknya yang memiliki kekutan fisik dan keahlian menjatuhkan (ngangkessaken lawan) disiapkan untuk diaduh pada

13 Ahmad Khalid, Makalah: diseminarkan di Universitas Islam Jember 02 Juni 2017, 6 
glanggang pencak. penulis mulai belajarpencak mulai tahun 1995. terjun ke glanggang pencak pada tahun 1997-2003.

Pada latihan itu, sang pendekar mengajarkan bagaimana cara memainkan pedang sebagai pemanasan proses aghelluk. Akhellukadalah proses menggunakan segala upaya kekuatan fisik di dalam arena pertarungan untuk saling menjatuhkan bahkan membanting lawan (ngangghessaken lawan akhelluk). setelah proses memainkan pedang lalu dilatih dengan kreatif memainkan ghonto ghonto (kunto)tangan dan kaki, maka si pendekar mengajarkan bagaimana cara memainkan gerakan tangan dan kaki (pendekar pategalan itu menyebutnya ghonto), proses gerakan ghonto.Ghonto (kunto)menurut masyarakat pegunungan adalah ketangkasan memainkan olah tangan dan kaki serta seluruh anggota badan dalam rangka membela diri dari serangan lawan atau musuh. kata ghonto (kunto) ini hampir sama dengan jurus bela diri. disini (dalam arena kompetisi) seorang pemain pencaks mulai mengkombinasi-kan kekuatan ghaib dengan kekuatan fisiknya, baca-bacaan, amalan kekuatannya mulai digunakan, adakalanya menggunakan jimat yang yakini pelantara kekuatan. lalu proses berikutnya adalah proses ketangkasan aghelluk(pendekar mengajarkan pokolan, dan teknik aghelluk) untuk menjatuhkan lawan. si petarung itu, menggunakan teknik yang telah diajarkan gurunya (pendekar).

Di dunia pencak (aghelluk) ada tingkatan-tingkatannya (ketangguhan peserta pencak), pertama peserta pencak yang tangguh biasanya peserta ini kategori senior dan berpengalaman. tetapi tidak semua senior itu tangguh dan masuk kelompok pertama, adakalanya peserta baru (anak mudah memiliki ketangguhan), maka dimasukkan ke kelompok tangguh. karena itu, proses pengaduan (chului/tunjuk) dalam areal pertarungan, si pendekar memilihkan pasangan yang sama-sama tangguh dan terkenal untuk diaduh akhelluk.

kedua tingkatan biasa. peserta pescaksilat tak terlalu tangguh dan tak terlalu lemah. biasa saja. cara mengukur tingkatan tangguh atau atau biasa saja diukur dari jumlah menag dan kalahnya dalam akhelluk menjatuhkan musuh. jika banyak menangnya maka dikolompokkan pada tingkatan tangguh. ketiga tingkatan pemulah atau anak kecil yang beru belajar pencak silat, biasanya tingkatan ini memiliki otot kecil (lemah) dan tidak berpengalaman ngangghessaken lawan, karena belum memiliki teknik yang handal dalam menjatuhkan lawan.

Proses berlangsungnya pencak (aghelluk) dalam glanggang umum (tarop) tanggungjawab berada pada pendekar, pendekar sebagai wasit dan pemegang aturan-aturan permainan pencak. sehingga proses pencak ini tidak ada kerusuhan dan bahaya bagi siapa saja, karena para pendekar memiliki pengetahuan yang lebih tinggi dan disegani oleh para perserta pencak. sehigga tidak ada pertengkaran dan permusuhan. satu hal lagi yang paling bagus dari nilai budaya pencak (aghelluk) adalah semua peserta yang diaduh dalam glanggang pertempuran harus mau aghelluk dengan sungguh-sungguh dan mengarahkan semua potensinya untuk saling menjantuhkan walaupun sebelumnya saling kenal, dan ketika selesai aghelluksaling meminta maafdan saling memaafkan, yang kalah tidak ada dendam yang menang tidak ada kesombongan.

Aturan aghelluk dalam pencak tidak pernah tertulis tetapi hanya dipahami dan dipegang teguh oleh semua pendekar dan peserta pencak, Aturan aghelluk antara lain;

- tangguh sama tangguh seimbang

- besar-sama besar seimbang

- kecil sama kecil seimbang 
- baru sama baru tapi seimbang

- proses aghelluk paling lama tiga ronda.

- aghelluktidak terlalu lama (jika lama artinya tidak ada yang jatuh atau tidak ada yang kalah maka pendekar yang memisahnyal ma ambhu),

- tidak boleh membawa alat tajam atau yang berbahaya.

- tidak boleh memukul dalam bentuk apapun

- menggunakan isyarat 'tepuk pada bagian punggung lawan' yang kuat atau menang pertanda menyerah atau kalah maka berakhirpula proses aghelluk.

- tidak boleh ada permusuhan di luar arena(dilain hari)

- proses aghelluk diakhiri dengan saling memaafkan dan berjabat tangan. ${ }^{14}$

\section{Siapa yang mengadakan pencak}

Pencak diadakan berdasar permintaan keluarga yang melangsungkan pernikahan putraputrinya atau salamatan yang dilakukan oleh masyarakat dengan memohon kepada ketua pencak persatuan. maka keluarga atau masyarakat menyuruh salah satu pendekar yang ada di desanya mengundang secara lisan kepada para pendekar persatuan, dan pendekar itulah yang mengundang atau membawah muridnya ke acara pencak tersebut.

Biaya pencak ditanggung oleh keluarga hajatan tersebut dan disumbang oleh persatuan masyarakat setempat. biaya itu berupa konsumsi, makan, rokok dan kebutuhan lainnya. sumbangan masyarakat tersebut berupa makanan atau konsumsi yang siap dimakan, bukan berupa uang melainkan konsumsi yang siap dinikmati oleh semua undangan dan masyarakat umum. tuan rumah boleh memberi uang kepada para pendekar dan peserta pencak tetapi hanya sebatas transportasi. Peneliti menemukan sedikit sekali keluarga hajatan memberikan uang transport kepada para pendekar dan peserta pencak, karena acara ini murni persatuan dan hiburan masyarakat bawean yang tidak dipungut biaya, tetapi hanya memberikan makan dan berkat dibawa pulang. kemungkinan kecil keluarga yang memberikan uang transport adalah desa yang tidak pernah mengikuti persatuan pencak, itupun tidak ditarjet hanya sebatas transport.

Penulis sangat tertarik pada budaya masyarakat dalam mensuk-seskan acara pencak ini, karena tidak merasa kesulitan dalam hal menyumbang konsumsi walaupun banyak jumlahnya, tetapi masyarakat merasa berat diminta sumbangan berupa uang walaupun sedikit jumlahnya. padahal kalau dihitung jumlah pengeluaran jika di uangkan lebih besar jumlahnya dibandingkan dengan sumbangan menggunakan uang. inilah tradisi orang desa pegunungan yang peneliti kagumi dan tidak dimiliki oleh orang kota atau orang yang mengaku maju di dunia ini.

\section{Sosial efek pencak (aghelluk)}

Sosial efek sebenanrnya banyak manfaat yang dapat diperoleh oleh masyarakat, dapat membantu ekonomi masyarakat dengan berjualan, dan temu teman, sahabat, lalu bercerita apa saja tergantung tujuan masing-masing yang hadir pada acara pencak tersebut, serta pihak pemerintah bisa dengan mudah bekerjasama dengan masyarakat dalam menyampaikan program kerja dan membangun keamanan masyarakat.

\footnotetext{
${ }^{14}$ Misnabi. Interview, 12 Maret 2018
} 


\section{Fungsi pencak antara lain.}

- pencak tidak lain adalah hiburan belaka untuk meramaikan pernikahan atau hajatan masyarakat.

- olahraga. pencak bagian olahraga fisik yang dapat berfungsi menyihatkan badan

- olah bathin. pencak disamping oleh badan juga dapat mengaktifkan olah bathin yang kuat karena diacara proses aghelluk banyak mengeluarkan tekanan bathin dan penggunaan ilmu kanoragan

- persatuan. pencak hanya sebagai persatuan yang dapat mengeratkan silaturrahim diantara para pendekar, para peserta pencak dan kepada semua masyarakat yang hadir diacara pencak.

- ukhuwah masyarakat bawean. pencak merupakan media untuk mengeratkan ukhuwah masyarakat bawean mengkokohkan persatuan NKRI dan menunjukkan masyarakat yang berbudaya dan saling memaafkan satu dengan yang lainnya, karena itu tidak ada permusuhan walaupun terjadi saling banting (ngangghessaken)itulah pesan-pesan yang dapat diambil pelajaran dari budaya pencak. ${ }^{15}$

\section{Tanda memulai dan mengakhiri acara pencak (aghelluk)}

Ketua persatuan pencak memainkan ketangkasan bermain pedang dan keindahan gerakan kaki yang dimiliki oleh sang ketua, lalu penyempurnaan keindahan bermain pedang dan kontu maka diikuti oleh tiga pendekar pilihan yang bagus memainkan pedang dan gerakan tangan-kaki dan keempat pendekar tersebut berpura-pura bertarung hanya untuk memikau para penonton dan penganten berdua. pencak pendekar tersebut disampin sebagai pembuka pencak, juga pada sisi terakhirsebagai tanda mengakhiri pencak adalah ditutup dengan pencak penganten. pencak penganten adalah pihak penganten berdua didudukkan di dalam terop lalu si pendekar itu bermain pedang dan keahlian mengelola ghonto (kunto/jurus).

\section{Budaya Ghuna-Ghuna ala pegunungan}

Budaya ghuna-ghuna adalah amalan-amalan atau ilmu kejelekan, orang-orang menyebutnya bagian dari ilmu sihir. sihir adalah keyakinan seseorang yang dapat menyakiti orang lain secara bathin, pengamal sihir biasanya memiliki kekebelan tubuh, suka menyendiri, pendengki, iri, sering tersinggung, tidak berani berhadapan, curang dan sebagainya.istilah ghuna-ghuna ini disebut di antaranya ash-sharf dan al-'athf. guna-guna ash-sharf ialah praktik sihir yang bertujuan mengubah hasrat dan keinginan manusia, seperti mencelakai orang lain, dan usaha memalingkan kecintaansuami kepada istrinya, dan sebaliknya. sedangkan guna-guna alathfadalah praktik sihir yang dapat membuat orang menjadi celaka, dan cenderung mencintai dan membencinya dengan cara-cara syaitan. (Ahmad Khalid, 2017:8)

Ada yang mananyakan, apakah gbuna-ghuna itu bagian dari sihir, apakah sihir itu bagian dari budaya masyarakat? jawabannya merujuk pada framewaork konseptual yang digunakan penelitian ini pendapat Philip Kotler, Gary Armstrong, Robbins dan Judge, Stok, Markic, Bertoncelj and Mesko, Ahmed dan Shafiq, Kotter and Heskett, Joson Martin,maka rujukan tersebut menunjukkan bahwa ghuna-ghuna itu bagian dari sihir. sihir itu bagian dari budaya negative masyarakat dan wajib bagi setiap umat Islam memeranginya, sebab mengamalkan ilmu sihir merupakan larangan besar dalam ajaran Islam, tetapi kalau sekedar mempelajarinya

\footnotetext{
${ }^{15}$ Data hasil observasi tanggal 13 Maret 2018
} 
dalam rangka untuk mencari kelemahan si pengamal sihir dan cara menangkalnya serta bagaimana memberantasnya, maka yang demikian tidak dilarang, yang dilarang adalah mempraktikkannya. jadi jelas menurut pandangan para ahli tersebut ghuna-ghuna atau sihir adalah budaya masyarakat, karena konsepsi budaya dalam tulisan ini adalah belief, value, norm, mitos, asumstion, perseption, artifak yang dikembangkan di masyarakat.

Pulau Bawean terkenal pulau yang dihuni oleh para jin dan pengembang ilmu sihir dan terkenal tempat angker dan penduduknya banyak melestarikan budaya ghuna-ghuna sehingga sering terdengar peryataan orang-orang setiap dusun terdapat pengamal ghuna-ghuna atau popular sebutan ilmu sihir (hasil penelusuran peneliti bahwa peryataan itu benar-benar berasal dari warga masyarakat 2017:9) tidak heran setiap desa banyak yang diduga memiliki ilmu sihir. ilmu sihir berangkali diasumsikan sebagai ilmu kekebalan diri oleh masyarakat nenek moyang bawean dan diyakini salah satu memperpanjang umur. makanya kebanyakan umur yang panjang masyarakat bawean diduga memiliki ilmu sihir, dan tidak bisa dilukai dengan benda tajam atau memiliki kekebalan diri (interview mengenai tanda-tanda para penagamal sihir, keheranan penulis adalah tanda-tanda tersebut sudah diketahui oleh semua warga, bukan rahasia lagi). tidak semua ilmu kekebalan itu adalah sihir. ilmu olah bathin, ilmu bela diri, ilmu kanoragan dan yang sejenisnya merupakan ilmu keselamatan diri dari bahahaya, ia tidak atau bukan ilmu sihir. jadi perbedaan ilmu kebhatinan, bela diri adalah disandarkan kepada Allah dan Rasulnya untuk mendapatkan ridlanya, sedangkan ilmu ghuna-ghuna atau sihir adalah ilmu yang dikembangkan bertemanan dengan jir kafir, manusia yang jahat dan niatnya untuk kejelekan dan membahayakan orang lain.

Sihir menurut keyakinan orang pegunungan warisan dari sesepuhnya. maka orang pegunungan mayoritas memiliki ilmu sihir karena diwarisi oleh sesepuhnya. walaupun anak cucunya tidak pernah belajarnya, tetapi ia kan diwarisinya dan secara alamiah pada akhirnya pun ia memahaminya dan memilikinya. proses penurunan ilmu sihir ini, menurut keyakinan orang pegunungan adalah proses tujuh turunan akan terus menurun kepada anak cucunya. keterangan dari warga bahwa proses menurunkan ilmu sihir kepada keturunannya melalui proses mimpi diajarkan secara langsung dan diajarkan secara lewat mimpi ketika ia sedang tidur. sang ayah atau kakek-buyutnya (pengamal ilmu sibir) datang kepada yang dikehendaki (penerusnya) dalam mimpi lalu dia mengajarkannya, disitulah si penerus itu ingat, hafal bacaabacaan dan ritual-ritualnya (keterangan para masyarakat yang di interview oleh penulis, keterangan masyarakat ini tentang cara-cara mewariskan ilmu sihir, semua informan menjawab) dan akhirnya ia menjadi pengamal ilmu sihir.

Mengapa dengan lingkungan pegunungan?lingkungan pegunungan merupakan tempat yang sunyi, terisolasi, tenang dari keramaian sehingga berpotensi besar bagi masyarakatnya untuk menyendiri dan bertapa atau mengasingkan diri untuk memperdalam ilmu tapa dan olah kebathinan. ilmu hasil bertapa dan mengolah kebatinan inilah yang seringkali tidak didasari dengan ilmu keislaman yang benar sehingga niat dan tujuannya mengarah pada kesaktian dan kesombongan. disinilah titik awal sesatnya manusia dan menjadi budak dan berteman dengan jin kafir. jin inilah yang kemudian menjadi sahabat setianya dan meminta tumbal.

Ilmu ghuna-ghuna atau sihir, tidak bisa dibuktikan oleh akal pikiran manusia tetapi bisa dibuktikan melalui hati dan amal-amalan khusus yang bisa membaca dan mendeteksi ilmu sihir yang dimiliki seseorang. biasanya orang yang pengamal ilmu sihir ketika ia menyihir seseorang, 
ia datang melalui mimpi kepada seseorang yang dituju berupa anjing, babi, munyet,dll, yang menyerupai pengamal sihir lalu orang yang dituju bisa menjadi sakit, banyak cara dilakukan penyihir dalam menyakiti orang lain.

Islam membenarkan sihir itu ada dibuat oleh kalangan jin dan manusia yang masuk syaithan. tidak perlu ditakuti dan tidak perlu ditantang. biasa saja dengan mengharapkan permohonan kesalamatan kepada Allah swt yang maha kuat. oleh karena itu islam mengajarkan bagaimana cara menangkal sihir yaitu membaca surat al-ikhlas, al-falaq dan annas 3 kali serta banyak berdoa memohon keselamatan pada Allah.

Penulis sering menyaksikan pengamal ilmu sihir memainkan panahnya berkeliaran dimalam hari bahkan pada suatu saat panah (panah menurut keyakinan orang-orang yang ada di pegunungan adalah perbuatan sihir seseorang sedang berlatih atau bertarung sesama pengamal sihir), itu kelihatan jatuh ke pohon di sebelah rumah, keesokan harinya pohon itu kering.Peristiwa masa lalu yang terjadi pada penulis, saat itu saya beru pulang dari pesantren, kelas 2 Madrasah Aliyah. satu lagi peristiwa shalat maghrib berjama'ah, saya menjadi imam shalat, makmumnya ada yang diisukan oleh masyarakat raja sihir dan banyak orang. ketika saya memulai membaca ayat pada rakaat yang kedua, saya tidak ingat satupun ayat al-qur'an (kirakira 1 menit terhenti). lalu setelah shalat ada satu makmum yang memberitahu bahwa saya dikunci oleh makmum sifulan, ia diisukan memiliki ilmu sihir yang handal.

Pernah suatu waktu, ayah saya sakit selama 1 bulan, secara medis tidak ada penyakit, pada malam hari penyakit ayah sudah mulai terasi, saya tidur disamping ayah, sekitar jam 1 malam ada makhluk yang datang menyerupai babi (celeng), ada muyit masuk ke dalam rumah lewat jendela. dipagi harinya ayah saya beru menceritakannya, saya waktu itu diam saja ketakutan (umur saya waktu itu kira-kira 10 tahun), Ayah saya memerintahkan kepada ibu untuk memanggil kyai yang dipandang bisa mengubatinya, lalu sang kyai itu, menceritakan sebabsebab sakitnya ayah saya yaitu disihir oleh 7 orang secara dikroyok, dan sihir itu dimasukan lewat dubur ayah ketika ayah sedang mandi di sungai dekat pekarang ayah, si penyihir itu tibatiba lewat di belakang ayah yang sedang mandi. sebelum itu, sebenarnya ada kejadian yang aneh yaitu ditemukan benda aneh yang ditanam di depan pintu selep padi yang biasa ayah lewati, ternya benda itu meleset dari ayah dan mengenahi kakek saya, lalu kakek saya sakitperutnya sangat besar dan mata buta di situ kakeh saya menemui ajalnya. kata kyai yang diundang kerumah waktu itu, bahwa perbuatan aneh itu adalah perbuatan orang yang dengki (pengamal sihir) yang ditujukan pada ayah saya tetapi mengenahi pada kakek saya.

Penulis sering menyaksikan liciknya orang yang pengamal ilmu sihir, hal ini menjadi korban paman saya, waktu itu baru pulang dari Malaysia dapat 3 hari, beliau merasa lehernya terasa gatel, sakit dan panas, beliau mengeluh kepada saya, lalu diperiksakan ke dokter, jawaban dokter biasa saja tumbuhporseghi(sejenis budun biasa, jenis penyakit kulit) tidak membahayakan sudah di obati oleh dokter, dapat 3 hari setelah diobati oleh dokter, beliau menjerit kesakitan lehernya dan menyebabkan beliau meninggal. setelah paman meninggal, bibi (istri paman), bercerita 1 hari sebelum paman merasa sakit, beliau didatangi tetangga yang pengamal sihir, paman menghormatinya sebagaimana menghormati tamu, lalu menyuguhkan minuman milo dan mikuit (oleh-oleh dari malaysia). disitulah si pengamal sihir memasukkan sihirnya melalui gelas yang diminum paman sampai paman menemui ajalnya.wallahu a'lam, 
kejadian itu sudah menjadi taqdir Allah, apakah itu ada perbuatan sihir dari golongan jin dan manusia hanya Allah yang maha mengetahuinya.

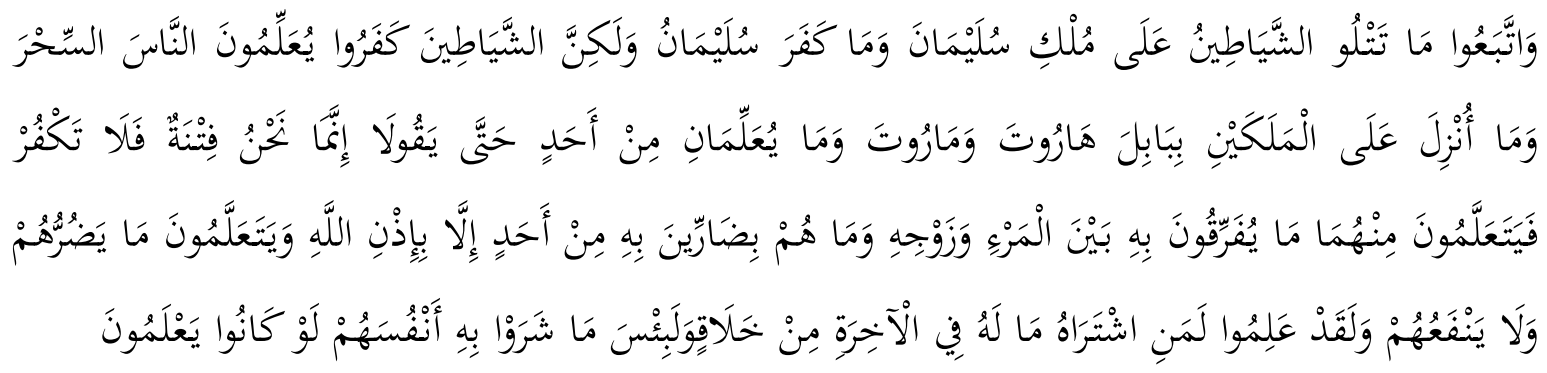

Artinya: Dan mereka mengikuti apa yang dibaca oleh syaitan-syaitan pada masa kerajaan

Sulaiman (dan mereka mengatakan bahwa Sulaiman itu mengerjakan sihir), padahal

Sulaiman tidak kafir (tidak mengerjakan sihir), hanya syaitan-syaitan itulah yang kafir (mengerjakan sihir). Mereka mengajarkan sihir kepada manusia dan apa yang diturunkan kepada dua orang malaikat di negeri Babil yaitu Harut dan Marut, sedang keduanya tidak mengajarkan (sesuatu) kepada seorangpun sebelum mengatakan: Sesungguhnya kami hanya cobaan (bagimu), sebab itu janganlah kamu kafir. Maka mereka mempelajari dari kedua malaikat itu apa yang dengan sihir itu, mereka dapat menceraikan antara seorang (suami) dengan isterinya. Dan mereka itu (ahli sihir) tidak memberi mudharat dengan sihirnya kepada seorangpun kecuali dengan izin Allah. Dan mereka mempelajari sesuatu yang memberi mudharat kepadanya dan tidak memberi manfaat. sesungguhnya mereka telah meyakini bahwa barangsiapa yang menukarnya (kitab Allah) dengan sihir itu, tiadalah baginya keuntungan di akhirat dan amat jahatlah perbuatan mereka menjual dirinya dengan sihir, kalau mereka mengetahui. ${ }^{16}$

Bagaimana pesantren berperan memberantas para pengamal ilmu sihir. secara tidak langsung pesantren melakukan perlawanan dengan mereka tetapi dilakukan secara halus yaitu dengan meyadarkan mereka shalat jama'ah, yasinan, tahlilan dan manaqiban serta kegiatan tarekat. kegiatan ini bagi mereka dimaksudkan agar mereka menyadari perbuatan dosanya dan bertaubat serta meninggalkan perbuatan terlarang tersebut. selain tersebut pesantren mengajarkan amalan-amalan khusus bagi masyarakat dan santri untuk menangkal sihir bahkan mengembalikannya kepada pemiliknya. tidak boleh menantang 'minta sihir/. Hasil penelusuran peneliti, beberapa informan memberikan penjelasan, bahwa Bawean pernah terjadi seorang kyai berpidato di atas mimbar lalu menantang para pengamal sihir, lalu kyai tersebut terjatuh dan memuntahkan darah dan menemui ajalnya. wallahu a'lam, pemeliti memahaminya karena taqdir Allah, kebenarannya hanyalah Allah yang mengetahuinya. kepada pengamal sihir, karena yang demikian sifat sombong, tetapi tidak boleh takut, karena sifat itu menandakan lemahnya iman, yang wajib ditakuti hanyala Allah, semua urusan kembalikan kepada-Nya.

\section{Budaya Toktok (persatuan aduan sapi)}

Penulis sebelum nyantri pelaku toktok, paman saya punya dua sapi petarung yang sering diadu ke berbagai daerah Bawean. dua paman saya bernamaAbdul Suaididan Ahmad Panjang. beliau sangat dikenal sebagai pemilik sapi yang tangguh dan mahal harganya.beliau berdua sering mendapatkan undangan pada acara toktokan (addhuan) sapi. dua paman saya tersebut

\footnotetext{
16 al-Qar'an surat al-Baqarah : 102
} 
memiliki sapi yang tangguh tiidak kalah tanding, harganya pun sangat mahal, sulit dicarikan musuhnya. setiap paman diundang diacara toktok itu, saya yang bertugasmembawa dan memegang sapinyasaat di adu (dalam lapangan tempat toktok) itu.

Toktok sapi merupakan budaya khas Bawean dan dikenal di daerah masyarakat pegunungan bahkan sudah menyeluruh di kepulauan Bawean. karena itu, aduan sapi ini, sudah menjadi tangghe'en (hiburan) masyarakat disetiap acara hiburan masyarakat seperti acara pernikahan, selamatan kampung, hajatan dan sebagainya, biasanya aduan sapi ini dimulai dari jam 13;00 hingga jam 16;00. mengapa jam 13;00 hingga jam 16;00 budaya toktok itu dimulaik, karena mengambil waktu condongnya matahari suapaya tidak terlalu panas. suhu yang terlalu panas membuat pertarungan sapi sebentar bahkan tidak mau bertarung, jika terlalu panas, akibatnya sapi itu mudah mengeluarkan bisa.

Tatacara budaya mengaduh sapi (toktok)antara lain;

a. tim panitia toktok melihat sapi para undangan satu persatu dan di ukur besar kecilnya

b. hasil pengukuran tersebut di musyawarahkan sesama tim guna menentukan lawannya (keseimbangan/besar sama besar)

c. sapi yang mau diaduh tali hidungnya (tongar) dilepas hanya menggu-nakan tali leher, terkadang tali leher itu, dibuat dari serabut bulu arren yang sudah rapuh, supaya sapi yang bertarung tidak tercekik dan tahan lama.

d. sapi yang dinyatakan kalah adalah sapi yang lari dari pertempuran-nya. setelah itu sapi yang lari ditangkap dan dipasang kembali tali hidung dan tali lehernya dan diserahkan kepada pemiliknya. ${ }^{17}$

Efek samping dari pelaksanaan budaya totok ini membantu ekonomi masyarakat karena penggemar toktok sangat besar jumlah datang dari berbagai desa se bawean. para penjual makanan dan restoran (warung makan)sekitar tempat toktok dapat menghasilkan keuntungan yang sangat besar. selain itu, toktok dapat mendongkrak tingginya harga sapi. toktok bagi masyarakat pegunungan menjadi hiburan yang digemari oleh setiap orang setelah budaya pencak (aghelluk). budaya toktok sudah berupa persatuan yang kuat bagi pengembala sapi jantan. segala resiko yang diakibatkan dari toktok, misalnyasapi ada yang mati, maka semua kerugian ditanggung oleh semua peserta persatuan.

Budaya toktok ini, bertentangan dengan syariat Islam, karena mengadu binatang hukumnya haram sebagaimana sabda Rasulullah saw

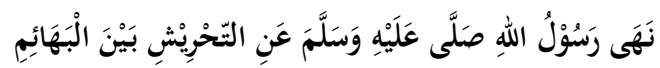

Rasulullah SAW melarang mengadu diantara binatang-binatang (Diriwayatkan oleh Imam Abu Dawud dari Ibnu Abbas r.a)

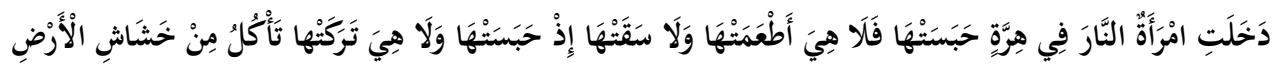

Seorang perempuan disiksa karena seekor kucing yang dipenjarakannya hingga mati, maka ia masuk neraka; ia tidak memberinya makan dan minum saat memenjarakannya, dan tidak pula melepasnya sehingga ia bisa mencari makan dari rerumputan bumi. ${ }^{18}$

Budaya ini sampai sekarang masih eksis dilakukan oleh persatuan, karena sulit dihentikan dan banyak penggemarnya, tidak ada perjudian, tidak ada minuman keras, tidak ada

17 Observasi 25 Oktober 2018

${ }^{18}$ Hadis diriwayatkan imam al-Bukhari, dalam Ahadits al-Anbiya:3482; Muslim dalam as-Salam:2242 
permusuhan, melainkan hanya menyiksa sapi. Murni hiburan masyarakat, tontonan masyarakat, mempererat persatuan dan justru menaikkan harga sapi, dan meningkatkan ekonomi para pedang makanan.

Usaha membendung perilaku toktok ini bisa melalui kesadaran individu bahwa hakikatnya sapi yang diaduh itu kesakitan dan menyiksanya. dengan demikian secara sendirinya (prores kesadaran) mereka akan menyadari dan berhenti sendiri tampa ada pemaksaan dan pertengkaran. pesantren dan alumninya berupaya keras untuk meningkatkan keimanan mereka (para pengadub) melalui mimbar pengajian umum, khutbah jumat, pidato, pengajian rutinan dimasyarakat,kyai atau ustadz menjelaskan ajaran Islam seperti keimanan, ketakwaan dan akhlaq mulia kepada semua makhluq. maka cara demikian lebih tepat dan bisa menyadarkan mereka bahwa mengaduh sapi merupakan hal yang dilarang dalam Islam dan akhlaq tidak terpuji. itulah model dan metode dakwah yang dilakukan kaum pesantren dalam melakukan perubahan sosial pada masyarakat toktok dan penggemarnya.

\section{Budaya ngalak chukok kalaot (gotong royong menangkap ikan dalam rangka tasyakuran pernikahan atau salamatan anak khatam al-qur'an)}

Budaya ini berkembang khusus di daerah pegunungan seperti dusun Petegelan, dusun celok-celok, dusun boto celeng, dusun pasar talaga, dusun jati-jati dan sekitarnya. budaya ini dilaksanakan berdasarkan kesepakatan warga masyarakat untuk membantu salah satu keluarga yang memiliki hajatan seperti pernikahan, salamatan, khataman al-qur'an, qadiran.qadiran budaya khusus masyarakat pategalan sejenis selamatan atas janji yang dibuatkan contoh kalau saya selamat sampai ke Malaysia saya akan akadir, kalau saya sampai ke bawean dengan selamat, saya akan akadir. jika nadar itu tercapai, maka ia akan segera menunaikannya. ${ }^{19}$

Qadiran adalah istilah orang pategalan dalam rangka menunaikan nadar (janji)seseorang yang tercapai cita-citanya atau hajat-hajatnya telah ditaqdirkan (diqabulkan/diterima)oleh Allah swt. penamaan ritual qadiran adalah karena dinisbatkan pada taqdir Allah swt yang telah mengabulkan doa atau janji-janji hambanya (nadar). kebiasaan nadar masyarakat pategalan dan sekitarnya diantaranya adalah ritual qadiran dan bernadar ziarah kemakam waliyah zainab. makam waliyah zainab diyakini oleh masyarakat pegunungan sebagai tempat yang barakah karena tiga alasan,pertama, beliau seorang peyiar ajaran Islam di pulau bawean dari kalangan wanita yang shalihah, pandai, wara' dan waliyah. kedua, makamnya berada dalam (areal)masjid dan penggagas masjid sebagai pusat ibadah dan islamisasi masyarakat bawean serta mobilisasi perubahan sosial masyarakat, ketiga, beliau seorang dai dan ulama kalangan perempuan yang sangat berjasa dalam mengislamkan masyarakat bawean khususnya masayarakat desa yang beliau tempati dan sekitarnya, sehingga pengaruh beliau sampai saat ini masih kuat seperti bahasa beliau tetap terjaga dengan baik yaitu bahasa jawa, karena beliau dari jawa. Para pengunjung diperkenalkan dengan tarikh beliau dalam berdakwa, dan dijelaskan pula tatacara berziarah ke makam wali Allah swt, supaya tidak terjadi kesyirikan yang bisa menghapus semua kebaikannya.

Jadi dua tradisi ini (aqadiran dan ziarah kubur) dilestarikan dengan baik. yang paling sering melakukan tradisi ini adalah mereka yang merantau keluar negeri seperti Malaysia, Singapur, Brunai Darussalam, dan para pekerja kapal baik jurusan luar negeri maupun luar negeri.

\footnotetext{
${ }^{19}$ Ahmad Khalid, 2017:11
} 
mereka, di dalam rantauan selalu merasa kesulitan, mendapatkan ujian, masalah dan sebagainya. kesulitan, ujian dan masalah tersebut diselesaikan dengan berbagai upaya dan tingkat terakhir adalah penyelesaian melalui nadzar. nadzar inilah berupa aqadiran dan ziarah makam waliyah zainab.Makam waliyah zainabterdapat di desa Diponggo Kecamatan Tambak Baewean Kabupaten Gresik.Masyarakatnyaberbahasa jawa tetapi bahasa jawa yang tidak memiliki keteraturan dengan makna lain masih banyak tercampur dengan bahasa local dan lughat local, hal ini wajar, mungkin karena beliau belum tuntas mengajarkan bahasa jawa yang tertib, beliau wafat mendahuluinya. ketidak teraturan bahasa jawa ala diponggo tersebut, menurut penulis merupakan keunikan tersendiri yang paling menarik dan berharga bagi budaya diponggo.

Menu atau makanan(suguhannya) berasal dari nasi gurih yang dimasak menggunakan santan kelapa dan ikannya dari ikan laut yang diambil secara gotong royong oleh masyarakat. isi dari ritual aqadiran itu adalahmembaca berzanji dengan suara yang indah dan membacaburdah,tablil dan kalimat thayyibabyang diambilkan dari ayat al-qur'an dan marbabanan. marhabanan sebutan orang-orang yang sedang asyik bershalawat kepada Rasulullah dan asik memuji rasulullah yang dilantunkan dengan suara merdu dan irama klasik yang indah sambil berdiri dan mengangkat kedua tangan, berlinangan air mata atas kecintaan pada Rasulullah.

Ritual ini banyak mengandung perbuatan baik yaitu mengkokohkan keimana kepada Allah, mengeluarkan sebagian hartanya untuk bersedekah kepada masyarakat, dan membangun komunikasi sesama warga melalui berkumpul dirumahnya diacara ritual qadiran. penyebutan masyarakat kadang aqadiran (ada huruf 'a'), kadang qadiran (tampa huruf 'a'), kadang kadiran pakai huruf k bukan q. keduanya (qadiran atau kadiran) dimaknai sama oleh masyarakat yaitu ritual qadiran, hanya urusan aksentuasi orang pedesaan yang agak sulit pengucapan huruf q.

Hal yang sangat menarik dari budaya ini adalah tidak semua orang bisa memasak nasi qadir, akan tetapi ada orang-orang khusus yang mewarisi cara memasaknya dan hasilnya sangat lezat, jadi keluarga yang mau melaksanakan qadiran ini menyuruhnya seharian penuh memasak untuk orang-orang sekampung. budaya ini sekarang sudah hampir hilang, karena penerus masyarakat yang peduli pada ritual qadiransudah tidak banyak yang melestarikannya.

Hasil ikan yang diambil secara gotong royong dilaut dimasak dirumah hajatan lalu disuguhkan dalam acara qadiran dan selebihnya dibagikan kepada tetangga terdekat, jika banyak lebihnya di bagikan kepada seluruh rumah yang ada atau dibakar bersama untuk menjaga hubungan baik seluruh lapisan masyarakat.

\section{Budaya salamatan janur katopak (salamatan desa)}

Isi janur katopak adalah nasi slamet. nasi slamet adalah nasih yang dimasak oleh warga masyarakat pategalan secara gotong-royong tampa ikan, rasa gurih yang dicampur dengan santen kelapa pilihan. kelapa pilihan adalah kelapa tidak terlalu tua dan tidak terlalu mudah. janur adalah daun kelapa yang masih mudah dianyam menjadi ketupat/katopak

Budaya selamatan kampung dilaksanakan setelah selesai menanam padi atau karena sering terjadi peristiwa yang menimpa masyarakat, semua warga masyarakat membawa beras masing-masing lalu dimasak jadi satu ditempat yang ditentukan, biasanya tempat yang dijadikan tempat memasak adalah thurung(lumbug). Thurung adalah tempat yang terbuat dari kayu jati penuh dengan ukiran kalsik dan sangat indah, bertingkat dua, difungsikan sebagai penyimpanan padi hasil panen bagi tingkat dua, sedangkan tingkat pertama difungsikan tempat 
tinggal (santai, istirahat, menerima tamu dll) bahkan digunakan tempat belajar dan tidur malam bagi anak-anak mudah. penulis sempat tidur di thurung itu mulai usia 5 tahun hingga 14 Tahun, tidak pernah tidur di dalam rumah. karena tingkat keramaian dan kesenangan lebih ramai dari pada rumah.

Thurung itu merupakan symbol perkumpulan pemuda masyarakat pegunungan, semua kegiatan kepemudaan dipusatkan di Thurung. karena itu, bagi masyarakat pegunungan, jika tidak memilikinya walaupun mereka memiliki rumah mewah dan besar, merasa kurang lengkap dan tidak nyaman. karena fungsinya yang vital yaitu tempat menyimpan padi dan benda yang berharga lainnya serta tempat yang nyaman dibuat menghirup udara segar.

Budaya selamatan ini diasumsikan sebagai penolak bahaya yang merintangi kesalamatan warga, lebih jauh lagi ritual budaya ini semula berasal dan hampir dekat-sama dengan ritual budaya agama nenek moyang yang berkembang di bawean pegunungan yaitu

Pertama, masyarakat menganyam janur kuning menjadi wadah, dihias rapi, cantik untuk diletakkan pada semua tempat dan jalan yang memiliki persimpangan, kandang sapi, sungai, sumber mata air dan diisi dengan makanan, nasi slamet dan sejenisnya yang dimasak di Thurung tersebut. Kedua, membuat ketupat, yang isinya adalah nasi yang dimasak tersebut lalu digantung di depan pintu rumah, pintu thurung, tempat-tempat yang dianggap angker atau tempat yang diyakini meminta tumbal dan sebagainya. tujuan dari nomor 1 dan 2 supaya ruh-ruh jahat atau jin merasa keyang dan tidak mengganggu ketenangan masyarakat. Ketiga, makan bersama dan sisanya dibagi rata dan tidak boleh dibawa masuk dalam rumah. (Observasi 22 Januari 2018)

Ritual ini bertentangan dengan ajaran islam, harus diganti dengan ritul yang diperbolehkan dalam Islam. dahulu ayah saya sering memimpin acara ini, dan beliau meluruskan dan mengkompromikan dengan ritual yang dibenarkan oleh syara', sehingga budaya ini sekarang lebih kental nilai-nilai keislamannya dan berjalan dengan baik, ritualritualnya yang dikembangkan anatara lain; tawassulan, baca tahlil, baca shalawat dan baca doa kesalamatan dunia dan akhirat. ${ }^{20}$

Kegiatan ini tidak membedakan status kekayaan dan tingkat kemiskinan yang terdapat dimasyarakat pegunungan, semuanya rukun dan bersatu diacara masak dan makan bersamadi Thurung, karena masyarakat menganggap nasi dan makanan yang dimasak bersama yang telah diberi doa oleh kyai atau tokoh masyarakat memebawa berkah dan diselamatkan oleh Allah.

Jadi peran pesantren dalam mengkompromikan ritual budaya ini sangat besar seperti ayah saya alumni pesantren Ruhul Amin Langkap pengasuhnya KH. Sulaimi, dan alumni pesantren Sokaoneng pengasuh Kyai Jamsuri. ayah saya (Muhammad Syafi'i) banyak memperbaiki ritual budaya masyarakat yang dianggap bertentangan dengan ajaran islam atas tuntunan dan binaan pesantren tersebut. apalagi dalam konteks kekinian dusun ini (pategalan dan sekkitarnya) sudah banyak alumni pesantren ternama di bawean maupun luar bawean.

\section{Budaya kalongan katopak dan jhubethe sape}

Budaya kalongan katopak dan jbubethe sapi adalah budaya para petani setelah selesai membajak sawah selama satu musim yaitu satu kali dalam setahun. karena masyarakat bawean pada umumnya membajak sawah hanya 1 kali dalam setahun yaitu dimusim hujan, sedangkan

\footnotetext{
${ }^{20}$ Data hasil observasi 22 Januari 2018
} 
pada musim kemarau persawahan dan lahan di daerah pegunungan tidak bisa dikelola karena kekurangan air, kecuali sawah yang dekat sungai.

Budaya ini (katopak dan jbubethe sapi)masih eksis di daerah pegunungan khususnya dusun pategalan dan sekitarnya.

Makna budaya kalongan katopak dan jhubethe pada sapi adalah supaya sapi yang dipekerjakan selama satu musim dapat selamat dan sehat serta taman yang ditanam di jauhi dari penyakit dan hama.

Komposisi ritual kalongan katopak dan jhubethe sapiantara lain: janur kuning, (buat ketupat), klaras (daun pisang yang kering) untuk membungkus jhubethe, jhubethe dan diikat dengan tali yang terbuat dari bambu mudah dan di kalungkan pada sapi. (Observasi lanngsung, 2 Pebruari 2018)

Sebelum proses pengkalungan tersebut, terlebih dahulu sapi tersebut dimandikan dengan air asma atau air doa yang sudah dicampur dengan temu lawak, temu merah, temuh besar, kunyit yang dihaluskan. ${ }^{21}$ Ditumbuh sampai halus, lalu dituangkan air dan terakhir disiramkan kesapi mulai dari kepala hingga keseluruh tubuhnya.

Kepercayaan masyarakat pada ritual budaya ini menyakini bahwa ritual ini terdapat nilainilai yang baik yaitu menyadarkan para petani akan keselamatan sapi yang telah dipekerjakan secara paksa dalam menyelesaikan pekerjaan sawah selama satu musim pertanianagar sapi-sapi yang dipekerja-kan itu menjadi sehat dan selamat dan menumbuhkan penghormatan pada binatang (sapi/kerboi). hubungan itu tidak hanya kepada sesama manusia, tetapi kepada binatang pun perlu berhubungan dengan baik, sehingga hubungan itu diperkuat dengan selamatan ritual tersebut.

satu musim yang dimaksud adalah satu tahun sekali bercocok tanam biasanya mulai turun hujan di musim hujan (biasanya mulai bulan januari hingga maret dan tergantung cuaca). setelah itu tidak ada lagi pertanian, kecuali lahannya dekat sungan atau ada perairan, sedangkan dimusim kemarau kebanyakan sawah di pegunungan tidak bisa dikelola karena kering.

Pelaksanaan ritual ini, para keluarga mengundang masyarakat kerumahnya dalam rangka salamatan yang dikemas dengan tawassulan, bacaan-bacaan surat al-qur'an, shalawat dan doa selamat, dan ditutup dengan makan bersama dan berkat atau sedekah kepada para undangan dan kepada saudara-saudaranya dan tetangga terdekatnya.

Perlukah budaya ini dikembangkan?budaya tersebut perlu dikembang-kan karena bagian dari peninggalan nenek moyang mereka, tetapi kewajiban kita sekarang bagaimana budaya itu disempurnakan dengan nilai-nilai keislaman sehingga dapat bermanfaat bagi umat Islam apalagi masyarakat pegunungan itu adalah seratus persen agamanya Islam dan Pengikut Nahdlatul Ulama. kemudian ritual budaya ini merupakan media kesempatan mengumpul-kan masyarakat sehingga dengan mudah mensyiarkan ajaran Islam yang rahmatan lil alamin (ahlussunnah wal jama'ah).

\section{KESIMPULAN}

Budaya masyarakat adalah sistem nilai-nilai,kepercayaan, artefak, asumsi yang mapandalam masyarakat. tujuh budaya masyarakat tersebut terdapat budaya yang nilai-nilai negative dan bertentangan dengan ajaran Islam. budaya amaen, budaya sihir dan budaya toktok.

\footnotetext{
${ }^{21}$ Data hasil observasi lanngsung, 2 Pebruari 2018
} 
karena ketiga budaya ini bertentangan dengan syariat Islam. tetapi ada empat budaya dari tujuh budaya tersebut yang mengandung motivasi positif yaitu budaya pencak, ngala chukok, kalongan katopak sapi, salamatan janur katopak. Empat budaya ini konstruktif, dapat memajukan dan membangkitkan semangat hidup bersama, akan tetapi perlu pengembangan pada proses kompromisme dengan nilai-nilai ajaran Islam dan dipertahankan melaui iinternalisasi kepada setiap anggota masyarakat. dengan begitu, masyarakat ini menjadi masyarakat yang mencintai budayanya dan berkembang sesuai dengan sistem nilai-nilai dan kepercayaannya. Kepada masyarakat bahwa budaya itu penting dikembagkan sebagai sarana mengembagkan diri dan budaya itu sebagai ciri khas masyarakat sekaligus sebagai aset yang paling berharga untuk dikembangkan dan sebagai pemersatu bangsas, kemajuan bangsa

\section{REFERENSI}

Ahmed, Mashal \&Shafiq,Saima. The Impact of Organizational Culture on Organizational Performance: A Case Study of Telecom Sector (Global Journal of Management and Business Research: AAdministration and Management) Volume 14 Issue 3 Version 1.0 Year 2014, Online ISSN: 2249-4588 \& Print ISSN: 0975-5853)

Forehand, G. A. and Von Gilmer, (1964). Environmental Variations in Studies of Organizational Behavior. Psychological Bulletin, 62, 361-382.

Hofstede, G. Bond, M. H. (1998). The Confucius Connection: from Cultural Roots to Economic Growth. Organ Dyn, pp. 5-21.

https:/ wmw.inc.com > encyclopedia: Corporate Culture - Encyclopedia

J. P. Kotter \& J.L. Heskett, 1992. Corporate culture and performance. New York: Free Press

Joson Martin, Organizational Culture and Organizational Change: How Shared Values, Rituals, and Sagas can Facilitate Change in an Academic Library, (ACRLApril 10-13, 2013, Indianapolis)

Kotler, Philip and Armstrong, Gary. 2006. Principles of Marketing. Penerjemah; Pop Sabran, Prinsip-Perinsip Pemasaran, Edisi 12. Jakarta; Erlangga

Kotter, J. P. \& Heskett, J. L. (1992). Corporate culture and performance. New York: Free Press.

Robbins, Stephen P and Judge1987. Organizational Behavior. New York: Printice Hall

Schein, E. H. (1990). Organizational culture. American Psychologist, 43 (2), 109-119.

Schein, E. H. (1995). Organizational culture. Campus Verlag, Frankfurt/New York

Stok, Markic, Bertoncelj and Mesko, Elements of organizational culture leading to business excellence(Preliminary communication) UDC 658:304.2:316.776. Zb. rad. Ekon. fak. Rij. • $2010 \bullet \operatorname{vol} .28 \cdot \mathrm{sv} .2 \cdot 303-318)$

Stok, Markic, Bertoncelj and Mesko, Elements of organizational culture leading to business excellence(Preliminary communication) UDC 658:304.2:316.776. Zb. rad. Ekon. fak. Rij. • $2010 \bullet$ vol. $28 \cdot \mathrm{sv} .2 \cdot 303-318), 306$

Schein, E.H. (1997). Organizational learning: what is new? available at:http:/ / learning.mit.edu (accessed January 1999).

Fakhar Shahzad, Rana Adeel Luqman, Ayesha Rashid Khan, Lalarukh Shabbir, Impact of Organizational Culture on Organizational Performance: An Overview 
Tujuh Budaya Masyarakat Pegunungan,..

INTERDISCIPLINARY JOURNAL OF CONTEMPORARY RESEARCH IN BUSINESS, JANUARY 2012 VOL 3, NO 9

Khalid Ahmad, Makalah: diseminarkan di Universitas Islam Jember 02 Juni 2017 